TEME, г. XLV, бр. 1, јануар - март 2021, стр. 165-178

Прегледни рад

https://doi.org/10.22190/TEME191106010I

Примљено: 6. 11. 2019.

UDK 331.45(4-12)

Ревидирана верзија: 6. 2. 2021.

Одобрено за штампу: 26. 2. 2021.

\title{
LEGAL FRAMEWORK OF OCCUPATIONAL SAFETY AND HEALTH POLICY IN THREE SOUTH EASTERN COUNTRIES
}

\author{
Aleksandra Ilić Petković* \\ University of Niš, Faculty of Occupational Safety, Niš, Serbia
}

\begin{abstract}
The legal framework for occupational safety and health is a key factor in effective policy implementation in this area at the local level. Employees in local self-government units perform tasks of immediate interest for the local population and, because of that, their workplace safety and health is an important issue. Given that there is not much research on the safety and health of employees in local self-government units in the countries of Southeast Europe, there is a need for the analysis of the protection provided by the applicable regulations. The conducted research shows that this category of employees is not specifically recognized either in the regulations on occupational safety and health or in the regulations on local self-government. It is desirable to improve the quality of legal protection which will contribute to the improvement of the workplace safety and health of these employees and will improve the quality of work in local self-governments.
\end{abstract}

Key words: employees, occupational safety and health, local self-government, legal framework, Southeast Europe.

\section{ПРАВНИ ОКВИР ПОЛИТИКЕ БЕЗБЕДНОСТИ И ЗДРАВЉА НА РАДУ У ТРИ ДРЖАВЕ ЈУГОИСТОЧНЕ ЕВРОПЕ}

\section{Апстракт}

Правни оквир безбедности и здравља на раду представља кључни фактор у ефикасној примени политике по том питању на локалном нивоу. Запослени у јединицама локалне самоуправе обављају послове од велике важности за локално становништво и због тога је њихова безбедност и здравље на раду важно питање. Како нема много истраживања о безбедности и здрављу на раду запослених у јединицама локалне самоуправе у државама Југоисточне Европе, постоји потреба за анализом њихове заштите кроз правну регулативу. Спроведено истраживање показује да ова категорија запослених није посебно препозната - ни у прописима о безбедности и

* Аутор за кореспонденцију: Александра Илић Петковић, Универзитет у Нишу,

Факултет заштите на раду, Чарнојевића 10А, 18000 Ниш, Србија, aleksandra.ilic@znrfak.ni.ac.rs 
здрављу на раду, а ни у прописима о локалној самоуправи. Пожељно је унапредити квалитет правне заштите, што ће допринети унапређењу безбедности и здравља на раду ових запослених и унапређењу квалитета рада локалне самоуправе.

Кључне речи: запослени, безбедност и здравље на раду, локална самоуправа, прописи, Југоисточна Европа.

\section{INTRODUCTION}

In modern times, employees are exposed to various types of risks to workplace safety and health, so the need for their prevention and promotion of safe and healthy working conditions is evident, since the maintenance of employees' health has an immeasurable effect on their productivity (Strategic Framework on Health and Safety at Work 2014-2020, 2014). Protection of the physical integrity of employees is considered an imperative of the modern system of occupational safety and health. The question is how to safeguard complete integrity of the employee - physical, mental, and moral (Neves \& Do Ceu, 2018). The answer to this question seems to be more complex when taking into account the existence of a whole variety of jobs that employees can perform. It is important to ensure safe and healthy working conditions for employees who perform activities of vital interest for the functioning of the local community and local population at the level of local self-government units, which is relevant for human resource management at the local level (Perlman, 2016).

There is no unified understanding of the concepts of local selfgovernment and occupational safety and health. Local self-government refers to public administration tasks performed by public institutions at the local level, which are different from the tasks performed at the state level (Pospiśill \& Lebiedzik, 2017). This refers to the right and opportunity for local authorities to regulate and manage a certain part of public affairs on the basis of their own responsibility, and in the interests of the local population, within the limits of the law (Ilić, 2013). It is a local management system aimed at harmonizing general and individual interests at the local level and protecting human rights and freedoms (Dimitrijević \& Vučetić, 2011). The local self-government directly ensures the protection of citizens' vital interests and its activities should contribute to improving the quality of life of the local population, with limited material, human and other resources at its disposal (Gecíková \& Papcunová, 2014).

Regarding occupational safety and health, many factors influence the understanding of this notion, such as the degree of development of socio-economic relations, dilemmas about the place and role of particular ideas in different sciences and disciplines, etc. (Anđelković, 2010). Labor law theoreticians have a specific view of workplace protection. General protection is a system of measures and activities that prevent or mitigate the harmful effects of working conditions and work processes on the safe- 
ty, health and working capacity of all employees. Special protection provides additional protection for young people, employees who perform high-risk jobs, people with disabilities and health problems, pregnant women and women who have recently given birth (Kulić \& Stojičić, 2016; Jovanović, 2015; Ivošević, 2007). Both types of protection refer to physical, mental and moral integrity (Marković, 1998).

There are several things to bear in mind when examining the position of employees in local self-government units in the context of occupational safety and health. Most importantly, as the activities carried out by the local self-government concern the vital interests of the local community, there is an indisputable need to pay special attention to the safety and health of the employees who perform these tasks. Taking into account the nature of the work they perform, one should not expect that their physical integrity is endangered, but the preservation of their mental and moral integrity would be a far greater challenge. The improved quality of legal protection of these employees gives a special contribution to the work of the public administration as a whole (Glennon at al, 2018). The implementation of health protection in different policies can involve the action at several levels of government, but it is true that the factors influencing the implementation of health protection in different policies at the local level are largely unexplored (Guglielmin at al, 2018). Since there is not much research on this topic, especially in the countries of Southeastern Europe, this paper will analyze the regulations on the labor status of employees in local selfgovernment units and regulations on occupational safety and health in three countries of Southeast Europe - Serbia, Montenegro and Croatia. Until recently, these countries formed an integral part of one state, but today each is independent. Serbia and Montenegro are EU membership candidates, while Croatia is an EU member, so it is important to see how its regulations treat the health and safety of employees in local self-government units. In all three countries, any ideas that can contribute to the improvement of the occupational health and safety system in general and in local self-government units is of great importance because the social conditions in these countries are similar.

\section{METHODS}

The normative method was used for collecting and processing the data in this paper. It was used for the analysis of constitutional documents in Serbia, Montenegro and Croatia in the parts pertaining to local selfgovernment and occupational safety and health. This was followed by the analysis of the laws of the aforementioned countries and they were classified in two categories - laws regulating local self-government and labor status of the employees in local self-government and laws regulating occupational safety and health. 
Finally, the results obtained for all three countries were compared. The authors first examined the results pertaining to constitutional documents, which was followed by the analysis of the laws in all three countries.

\section{RESULTS}

\section{The Republic of Serbia}

The significance of local self-government in the Republic of Serbia is observed in the fact that it is mentioned in the Constitution (2006) in various contexts, but the employees in local self-government units are not specifically recognized. The Law on Local Self-Government (2007) does not deal with persons' employment status in local self-government units and their workplace safety and health, but there are several provisions concerning the employment status in terms of the obligation or possibility of starting an employment relationship. The regulation that directly deals with the labor status of the employees in local self-government units in Serbia is the Law on Employees in Autonomous Provinces and Local Self-Government Units (2016). The law itself stipulates which categories of persons are considered employees and clearly determines the scope of persons to whom it applies. Employees are state officials, civil servants and state employees. This law thoroughly regulates the positions of officials and civil servants, while the rights and duties of state employees are regulated by general labor regulations, unless otherwise provided by this law.

Workplace safety and health of employees is one of the most important human rights and, in Serbia, it is guaranteed by the Constitution, which stipulates that everyone has the right to safe and healthy working conditions and necessary workplace safety (2006). The full meaning of constitutional proclamations is obtained by examining the Law on Occupational Safety and Health, which is the basic Serbian regulation in this field (2005). This law stipulates that occupational safety and health must be provided to all participants in the work process, but also to all persons currently in the working environment. As regards the occupational safety and health status of the employees in local self-government units, it can be noted that the Law on Occupational Safety and Health applies to these persons, i.e. there are no special provisions excluding them from its application or providing any special provisions that would apply to them.

\section{The Republic of Montenegro}

There are several provisions in the Constitution of Montenegro pertaining to self-government (2007). It explicitly guarantees the right to local self-government and prescribes that the law should regulate the system of local self-government. When it comes to employees in local self- 
government units, the Constitution recognizes the President of the Municipality as a person whom the Government can dismiss from office if he/she does not exercise his/her duties for a period longer than 6 months. The basic legal document regulating the system of local self-government in Montenegro is the Law on Local Self-Government (2017). This law defines local self-government units, regulates their status, jobs, property and bodies, but also identifies local officials, local civil servants and local employees and determines their status.

The Constitution of Montenegro stipulates that everyone shall have the right to work, free choice of occupation and employment, fair and humane working conditions, protection during unemployment, and adequate earnings. It also guarantees the right to limited working hours, paid holidays and occupational safety. The right to workplace safety is further regulated by the Law on Occupational Safety and Health (2014). The provisions of this law apply to all the employees in state bodies and state administration bodies, including the local self-government units, in the territory of Montenegro. Furthermore, they apply to all persons who are present at their place of employment in any work process on any legal basis. This law determines the scope of persons entitled to occupational safety and explicitly prescribes that its provisions pertain to the employees in local self-government units.

The Law on Local Self-Government does not recognize the right to workplace safety and health of local officials, local civil servants and local employees. It prescribes that the law governing the establishment of employment relationship in state bodies, the rights, obligations and responsibilities of civil servants and state employees, as well as general labor regulations, shall apply to the rights, obligations and responsibilities of these persons not regulated by this law. Therefore, this implies the application of the Labor Law of Montenegro (2008), which provides for workplace safety and health, as well as special workplace protection of women, young and disabled persons.

\section{The Republic of Croatia}

The right to local self-government is regulated by the Constitution of the Republic of Croatia (2010). It proclaims that citizens shall be allowed to realize this right through their local representative bodies. The Constitution does not recognize employees in local self-government units in a special way, but this matter is managed by specific laws. The Law on Local and Regional Self-Government (2001) does not contain provisions on local civil servants, but contains several provisions on their training. The civil servants in local self-government are encouraged to continue their vocational training and development. The basic law pertaining to local civil servants in Croatia is the Law on Civil Servants and Employees in Local and Regional Self-Government (2008). This law defines the notion of civil servant and employee and thoroughly regulates their labor status. Fur- 
thermore, in Croatia there is a special law regulating their salaries - the Law on the Salaries in Local and Regional Self-Government (2010).

Workplace safety and health is recognized in the Constitution of Croatia only indirectly. It stipulates that each person has the right to work, freedom of work, right to freely choose the occupation etc. The Constitution specifies that the longest working hours are determined by the law and that each employee shall have weekly rest and paid annual holiday, as well as the right to earnings. In the part referring to the rights of employed persons, there is a provision that guarantees the right to health protection to everyone, in accordance with the law. The right to workplace safety and health is regulated by the Occupational Safety Law (2014). This law is applied in all the activities in which employees work with an employer, with certain clearly defined exceptions (e.g. police jobs). Therefore, this law applies to the employees in Croatian local self-government units. They are not in any way exempt from its application.

\section{DISCUSSION AND CONCLUSION}

The Constitution of Serbia does not deal with employees in local self-government units. Moreover, the Law on Local Self-Government deals neither with the regulation of the labor status of these persons, nor their occupational safety and health. Neither does the Law on Employees in Autonomous Provinces and Local Self-Government Units provide an overview of workplace safety and health, although it contains several provisions on this. The fact that the regulations on local self-government and employees in local self-government units do not recognize the issue of workplace safety and health of their employees highlights the necessity of analyzing the regulations pertaining to occupational safety and health. In Serbia the right to safe and healthy working conditions is guaranteed by the Constitution, which demonstrates a clear determination to ensure safe and healthy working conditions and necessary work protection in its broadest sense. This right is elaborated on in the Law on Occupational Safety and Health (2005). The law also applies to the employees in local self-government units. The right to occupational safety and health is guaranteed to them by the Law on Employees in Autonomous Provinces and Local Self-Government Units as well, since it stipulates that employees have the right to working conditions that will not endanger their life and health, the right to technical and other conditions necessary for work, the right to protection against threats, attacks and all other things that will endanger their occupational safety and health. At the request of an employee, the employer is obliged to take measures to protect his/her workplace safety and health and the employee has the right to protection against abuse at work. The protection of employees shall be provided by the employer. Therefore, employees are guaranteed both general and special protection at work. This 
means that the right to protection of physical integrity from harmful effects of working conditions is guaranteed, as well as the right to protection of moral integrity from threats and attacks.

In the case of employees in local self-government units, the issue of their moral and mental protection is of special importance. It is clear that all these regulations guarantee the protection of physical integrity, but when one takes into account the nature of the tasks these persons perform, there is a much greater need for the preservation of their mental and moral integrity. The aforementioned regulations in Serbia only partially recognize this need. This issue is somewhat regulated by some other laws regarding the prohibition of discrimination, abuse at work, etc.

The Constitution of Montenegro and the Constitution of Serbia have a number of similar provisions pertaining to local self-government. Unlike the Constitution of Serbia, which does not acknowledge the employees in local self-government units, the Constitution of Montenegro contains a provision according to which the Government can dismiss the municipal president from office if he/she does not exercise his/her duties for a period longer than 6 months. A significant difference in the regulation of the labor status of employees in local self-government units between Serbia and Montenegro is that the Law on Local Self-Government in Montenegro regulates the labor status of these persons. In Serbia, this issue is regulated by a separate law the Law on Employees in Autonomous Provinces and Local SelfGovernment Units. What these two countries have in common is that both contain legal documents that methodically regulate the system of local selfgovernment and the persons who work in it.

With regard to occupational safety and health, in Serbia and Montenegro this right is guaranteed by constitutional documents almost identically. Neither the Constitution of Montenegro nor the Constitution of Serbia recognize the need for special protection of some categories of employees in local self-government. In Montenegro, the right to occupational safety is regulated by the Law on Occupational Safety and Health, which, like the Law on Occupational Safety and Health in Serbia, determines the scope of persons to whom it applies. However, there is one significant difference between the two laws. The Montenegrin law clearly stipulates that its provisions also apply to employees of local self-government units, while the Serbian Law on Occupational Safety and Health does not explicitly stipulate and prescribe this. The Law on Local Self-Government of Montenegro does not recognize the right to occupational safety and health of local officials, local civil servants and local employees, but implies the implementation of the Labor Law of Montenegro, which guarantees the safety and health of employees at work. This provision is almost identical in the Serbian Labor Law.

The Constitution of the Republic of Croatia guarantees the right to local self-government similarly to the constitutions of Montenegro and 
Serbia. The Croatian Constitution has gone the farthest in regulating this right as it contains the largest number of provisions on this issue. Many of the issues regulated by laws in Serbia and Montenegro (e.g. financing and the revenues of local self-government units) are regulated by the Constitution in Croatia. The Constitution of Croatia does not recognize employees in local self-government units in a special way, nor do the constitutions of Serbia and Montenegro (except for the aforementioned provision of the Constitution of Montenegro authorizing the Government to dismiss the President of the $\mathrm{Mu}-$ nicipality in certain cases), but this matter is regulated by legal documents. The Law on Local and Regional Self-Government is a basic law governing local self-government, such as the Law on Local Self-Government in Serbia and the Law on Local Self-Government in Montenegro. These three laws do not regulate the labor status of employees in local self-government units, but the Croatian law regulates the professional development and training of local civil servants, which can lead to the conclusion that continuous education is recognized as particularly important for the local self-government. The basic law dealing with local civil servants in Croatia is the Law on Civil Servants and Employees in Local and Regional Self-Government. As can be seen, in Croatia and Serbia, the labor status of these persons is regulated by special laws, while in Montenegro this is contained in the Law on Local SelfGovernment. It can be noted that in the regulation of the labor status of local civil servants, Croatia went the longest way, as this country adopted a special law on the salaries of these persons.

Workplace safety and health are not explicitly prescribed by the Constitution of Croatia, unlike the Constitution of Serbia and the Constitution of Montenegro. The basic Croatian law regulating the issue of occupational safety is the Occupational Safety Law. This law applies to employees in the local self-government units of Croatia, because they are not exempt from its application. Therefore, Croatian employees in local self-government units are protected by this law the same as in Serbia and Montenegro. It is noticeable that employees in local self-government units are explicitly recognized only in the Law on Occupational Safety and Health of Montenegro, while in Serbia and Croatia, the laws on occupational safety and health apply to them without any special emphasis.

Bearing in mind that local self-government can be understood as the right and ability of local authorities to regulate and manage an extensive part of public affairs under their responsibility and in the interests of the local population, within the limits of the law (Demmke, 2005), it is not insignificant who will perform the jobs in local self-government units and how they will do it. This is why there are special laws on employees in local selfgovernment units that regulate their working status in detail, different from the regulations that establish a general regime of labor relations. Values such as professionalism, efficiency, legality, transparency and the like, are expected from the employees in local self-government units, as well as the state 
employees (European Charter of Local Self-government, 1985); therefore, it is necessary to provide safe working conditions. Given that there is not much research on the safety and health of employees of local self-government units in the countries of Southeastern Europe, the analysis of their legal protection provides an overview of the advantages and disadvantages of existing regulations (Table 1).

Table 1. Overview of the regulations on occupational safety and health in local self-government units in Serbia, Montenegro and Croatia.

\begin{tabular}{|c|c|c|c|}
\hline State & $\begin{array}{l}\text { Regulations on } \\
\text { local self- } \\
\text { government }\end{array}$ & $\begin{array}{l}\text { Regulations on the employees } \\
\text { in local } \\
\text { self-government units }\end{array}$ & $\begin{array}{c}\text { Regulations on } \\
\text { occupational } \\
\text { safety and health } \\
\end{array}$ \\
\hline $\begin{array}{l}\text { Republic of } \\
\text { Serbia }\end{array}$ & $\begin{array}{c}\text { Law on Local } \\
\text { Self-Government }\end{array}$ & $\begin{array}{c}\text { Law on Employees in } \\
\text { Autonomous Provinces and } \\
\text { Local Self-Government Units }\end{array}$ & $\begin{array}{c}\text { Law on } \\
\text { Occupational } \\
\text { Safety and Health }\end{array}$ \\
\hline $\begin{array}{l}\text { Republic of } \\
\text { Montenegro }\end{array}$ & $\begin{array}{c}\text { Law on Local } \\
\text { Self-Government }\end{array}$ & $\begin{array}{c}\text { Law on Local } \\
\text { Self-Government }\end{array}$ & $\begin{array}{c}\text { Law on } \\
\text { Occupational } \\
\text { Safety and Health }\end{array}$ \\
\hline $\begin{array}{l}\text { Republic of } \\
\text { Croatia }\end{array}$ & $\begin{array}{c}\text { Law on Local } \\
\text { and Regional } \\
\text { Self-Government }\end{array}$ & $\begin{array}{c}\text { Law on Civil Servants and } \\
\text { Employees in Local and } \\
\text { Regional Self-Government } \\
\text { Law on the Salaries } \\
\text { in Local and Regional } \\
\text { Self-Government }\end{array}$ & $\begin{array}{l}\text { Occupational } \\
\text { Safety Law }\end{array}$ \\
\hline
\end{tabular}

Based on the conducted research, we can draw a number of conclusions. In the legal systems of Serbia, Montenegro and Croatia, employees in local self-government units are recognized as a separate category of employees whose employment status varies to a certain extent from general labor relations. The constitutional documents of these countries do not deal with the position of employees in local self-government units, but this issue is regulated at the level of legal documents in all three cases. In Serbia, the employment status of these persons is regulated by the Law on Employees in Autonomous Provinces and Units of Local Self-Government, in Montenegro by the Law on Local Self-Government, and in Croatia by the Law on Civil Servants and Employees in Local and Regional Self-Government. All these laws are relatively new, which suggests that the legislator has only recently started to deal with the legal status of these persons.

In all three countries there are special laws that regulate the issue of occupational safety and health and none of these laws recognize employees in local self-government units in a special way, as a category that requires additional protection compared to the protection guaranteed to all other categories of employees. Moreover, the General Directive 89/391 (European Union (EU). Directive 89/391/EEC - OSH "Framework Directive", 1989), although with some exceptions, does not recognize the 
need for special protection of employees in local self-government units either. This applies to ILO regulations as well.

Although this issue is not specially treated, it can be elaborated on in the bylaws. It is necessary to pay attention to the protection of human integrity as a whole - physical, mental and moral. Employees in local selfgovernment units should be especially protected in terms of their mental and moral integrity, because the understanding of psychosocial factors of occupational safety would contribute to reducing injuries, diseases and absence from work (Slany at al, 2014). Modern safety legislation in these countries should respond to the growing dangers of these two types of employee integrity, because work-related psychosocial risks can lead to deterioration of the mental health of employees, cardiovascular diseases and musculoskeletal organ disorders (EU-OSHA, 2017). The risk of workplace violence should also be mentioned, as it is becoming more and more frequent (Robbins, 2018). These are the dangers which should be specifically addressed in the safety legislation, because the legislative framework is essential for ensuring a high level of occupational safety. This would also contribute to reducing the costs of occupational injuries and professional diseases, which, for example in the European Union, amount to at least 476 billion euros a year (EU-OSHA, 2018).

Based on this discussion, it can be concluded that employees in local self-government units in Serbia, Montenegro and Croatia enjoy a special employment status, which is regulated by special legal documents different from the general labor relations. Unlike labor legislation, workplace safety and health of the employees in local self-government units of these countries is not regulated by special documents, nor are these persons recognized as special categories of employees in any way. Here there is room for improvement of the legislation in the form of bylaws, because these categories of employees could be treated in a special way, given the nature of the jobs they perform. This shall be an additional contribution to the modernization of local self-government (Copus \& Steyvers, 2017) in keeping with the current trend of efficient use of human and material resources (Santrić Milicević at al., 2018), as well as to the much needed health promotion (Gecíková \& Papcunová, 2014) in these countries. The improvement of legal regulations will result in better performance of employees (Lozina \& Klarić, 2008) since the development of local self-government depends on social and personal factors (Arsenijević, Kastratović \& Nešić, 2017), all of which will contribute to its better functioning.

Also, it can be concluded that the legal regulations in all three countries significantly follow the current trends in the legal framework of occupational safety and health, but little attention is paid to the specifics of certain categories of employees, such as local officials. With this in mind, there are some particular measures that the mentioned countries 
could adopt in order to improve the safety and health of employees in local self-governments.

Improving the mechanism for controlling the application of occupational safety and health regulations is one of the measures that could be recommended. As in some countries local authorities and municipalities have powers to inspect, either using their own regulations or with delegation from central authorities (ILO, 2012), this could be a good example for the control of occupational safety and health regulations in local self-government units. Supervision over the implementation of occupational safety and health regulations is an important precondition for their consistent implementation. The introduction of local inspectors with such powers would significantly reduce the burden on national inspection bodies and increase efficiency in the implementation of regulations. In this way, more space would be given for preventive and advisory action of local inspectors.

Furthermore, as the prevention of occupational injuries and professional diseases is one of the requirements of the legislation of the mentioned countries, it is recommended to organize an occupational medicine service dedicated exclusively to employees in local self-government units. Apart from being preventive, such a service would have the role of providing health care to local self-government employees. As a large number of people are employed in the local self-government, this would reduce the pressure on other health institutions. Preventive action of such a service would reduce the risks to the mental health of employees, which is greater than the risk to their physical health, given the nature of the work they perform. However, as local officials frequently communicate with citizens, the risks to their physical integrity, such as work intensity, rapid changes in work procedures, conflict situations, and possible workplace violence, should not be neglected.

The conducted study could be a good basis for further research on specific risks for occupational safety and health of officials in general, both civil and local. Certain categories of civil servants, such as employees in penitentiaries, police or the army, are exposed to greater risks to their occupational safety and health. Therefore, the consideration and possible improvement of the legal framework on their occupational safety and health would be important for enhancing the protection of these categories of employees.

\section{REFERENCES}

Anđelković, B. (2010). Osnovi sistema zaštite. [Fundamentals of Protection System] Niš: Fakultet zaštite na radu.

Arsenijević, O., Kastratović, E., \& Nešić, S. (2017). Attitudes of the Employees on Education in Local-Self-Government. Economic Analysis, 50(1-2), 77-96.

Copus, C., \& Steyvers, K. (2017). Local Leadership and Local Self-government: Avoiding the Abyss. Lex Localis, 15(1), 1-18. 
Council of Europe. European Charter of Local Self-government (1985). Retrieved from https://rm.coe.int/168007a088

Demmke, C. (2005). Are civil servants different because they are civil servants? Luxembourg: European Institute of Public Administration.

Dimitrijević, P. \& Vučetić, D. (2011). Sistem lokalne samouprave. [Systemof Local Government] Beograd: Službeni glasnik.

Directive 89/391/EEC - OSH "Framework Directive" (1989). Retrieved from https://osha.europa.eu/en/legislation/directives/the-osh-framework-directive/1

EU-OSHA (2017). An international comparison of the cost of work-related accidents and illnesses. Retrieved from https://osha.europa.eu/en/publications/internationalcomparison-cost-work-related-accidents-and-illnesses/view

EU-OSHA (2018). Management of psychosocial risks in European workplaces - evidence from the second European survey of enterprises on new and emerging risks (ESENER-2) - Executive summary. Retrieved from https://osha.europa.eu/en/ tools-and-publications/publications/management-psychosocial-risks-europeanworkplaces-evidence/view

Gecíková, I., \& Papcunová, V. (2014). Using of strategic management tools in conditions of local self-government in Slovakia. Procedia - Scotland Behavioral Sciences, $110,969-978$.

Glennon, R., at al. (2018). Public Sector "Modernisation': Examining the Impact of a Change Agenda on Local Government Employees in England. Australian Journal of Public Administration, 77(2), 203-221.

Guglielmin, M., at al. (2018). A scoping review of the implementation of health in all policies at the local level. Health Policy, 122(3), 284-292.

Ilić, M. (2013). Lokalna samouprava. [Local Government] Vranje: Učiteljski fakultet.

ILO (2012). Training Package on Development of a National Program of Occupational Safety and Health, Module 2 Introduction to the National Occupational Safety and Health System. Retrieved from http://www.oit.org/wcmsp5/groups/public/---ed_ protect/---protrav/---safework/documents/instructionalmaterial/wcms_215449.pdf

Ivošević, Z. (2007). Radno pravo. [Labor Law] Beograd: Službeni glasnik.

Jovanović, P. (2015). Radno pravo. [Labor Law] Novi Sad: Pravni fakultet.

Kulić. Ž. \& Stojičić, S. (2016). Radno pravo. [Labor Law] Beograd: Zavod za udžbenike.

Lozina, D., \& Klarić, M. (2008). Local Public Servants and Employees in the Republic of Croatia: Legal Position and Obligations. Lex Localis, 6(4), 413 - 428.

Marković, Ž. D. (1998). Sociologija bezbednog rada. [Sociology of Safe Work] Niš: Prosveta.

Neves, P., \& Do Ceu, M. (2018). On (scientific) integrity: conceptual clarification. Medicine health care and philosophy, 212, 181-187.

Perlman, B. (2016). Human Resource Management at the Local Level: Strategic Thinking and Tactical Action. State and Local Government Review, 48(2), 114-120.

Pospíśill, P., \& Lebiedzik, M. (2017). Some of the theoretical basis of local selfgovernment in the Czech Republic. Danube: Law and Economics Review, $8(1), 31-43$.

Ristić, G. (2010). Zaštita na radu vs. bezbednost i zdravlje na radu. In Živković, Lj. (Ed.): Zbornik radova Pedeset godina organizovanje zaštite na radu u Srbiji (223-228). Niš: Fakultet zaštite na radu.

Robbins, K. (2018). Workplace Violence - The Joint Commission's Sentinel Alert. Nephrology Nursing Journal, 45(3), 291-293.

Santrić Milicević, M., at al. (2018). Strengthening the public health workforce: An estimation of the long-term requirements for public health specialists in Serbia. Health Policy, 122(6), 674-680. 
Legal Framework of Occupational Safety and Health Policy in Three South Eastern Countries 177

Slany, C., at al. (2014). Psychosocial work factors and long sickness absence in Europe. International Journal of Occupational and Environmental Health, 20(1), 1-25.

Strategic Framework on Health and Safety at Work 2014-2020 (2014). Retrieved from http://eur-lex.europa.eu/legal-content/EN/TXT/?uri=COM:2014:332:FIN

Ustav Republike Crne Gore [Constitution]. (2007). Retrieved from http://www.skupstina. me/images/dokumenti/ustav-crne-gore.pdf

Ustav Republike Hrvatske [Constitution] (2010). Retrieved from http://www.sabor.hr/ ustav-republike-hrvatske

Ustav Republike Srbije [Constitution] (2006). Retrieved from http://www.paragraf.rs/ propisi/ustav_republike_srbije.html

Zakon o bezbednosti i zdravlju na radu Republike Srbije [Law on Occupational Safety and Health] (2005). Retrieved from https://www.minrzs.gov.rs/files/doc/bezbednost_ na_radu/Dopuna_Nov/Zakon_o_bezbednosti_i_zdravlju_na_radu_nezvanicno_pr eciscen_tekst.pdf

Zakon o lokalnoj i područnoj (regionalnoj) samoupravi Republike Hrvatske [Law on Local and Regional Self-Government] (2001). Retrieved from https://uprava.gov.hr/oministarstvu/ustrojstvo/uprava-za-politicki-sustav-i-organizaciju-uprave/lokalna-ipodrucna-regionalna-samouprava/842

Zakon o lokalnoj samoupravi Republike Crne Gore [Law on Local Self-Government] (2017). Retrieved form http://www.mju.gov.me/biblioteka/zakoni

Zakon o lokalnoj samoupravi Republike Srbije [Law on Local Self-Government] (2007). Retrieved from http://www.mduls.gov.rs/doc/dokumenta/Zakon\%20o\%20 lokalnoj\%20samoupravi.pdf

Zakon o platama u lokalnoj i područnoj (regionalnoj) samoupravi Republike Hrvatske [Law on the Salaries in Local and Regional Self-Government] (2010). Retrieved from https://narodne-novine.nn.hr/clanci/sluzbeni/2010_03_28_665.html

Zakon o radu Republike Crne Gore [Labor Law] (2008). Retrieved from http://www.mju. gov.me/biblioteka/zakoni

Zakon o radu Republike Srbije [Labor Law] (2005). Retrieved from https://www.minrzs. gov.rs/sektor-za-rad-zakoni.html

Zakon o službenicima i nameštenicima u lokalnoj i područnoj (regionalnoj) samoupravi Republike Hrvatske [Law on Civil Servants and Employees in Local and Regional Self-Government] (2008). Retrieved form https://uprava.gov.hr/UserDocsImages //Lokalna\%20samouprava/2011//Zakon\%20o\%20slu\%C5\%BEbenicima\%20i\%20 namje \%C5\%A1tenicima\%20u\%20LPRS.pdf

Zakon o zaposlenima $u$ autonomnim pokrajinama $i$ jedinicama lokalne samouprave Republike Srbije [Law on Employees in Autonomous Provinces and Local SelfGovernment Units] (2016). Retrieved from http://www.mduls.gov.rs/doc/ dokumenta/Zakon\%20o\%20zaposlenima\%20u\%20autonomnim\%20pokrajinama $\% 20 \mathrm{i} \% 20$ jedinicama\%20lokalne\%20samouprave.pdf

Zakon o zaštiti i zdravlju na radu Republike Crne Gore [Law on Occupational Safety and Health] (2014). Retrieved from http://www.mju.gov.me/biblioteka/zakoni

Zakon o zaštiti na radu Republike Hrvatske [Law on Occupational Safety] (2014). Retrieved from http://www.mrms.hr/ministarstvo-rada-i-mirovinskoga-sustava/ zastita-na-radu/katalog-zakona-i-propisa/ 


\title{
ПРАВНИ ОКВИР ПОЛИТИКЕ БЕЗБЕДНОСТИ И ЗДРАВЉА НА РАДУ У ТРИ ДРЖАВЕ ЈУГОИСТОЧНЕ ЕВРОПЕ
}

\author{
Александра Илић Петковић \\ Универзитет у Нишу, Факултет заштите на раду, Ниш, Србија
}

Резиме

Безбедност и здравље запослених представља један од приоритетних изазова савременог друштва. Правни оквир безбедности и здравља на раду је кључни фактор у ефикасној примени политике по том питању на свим нивоима, почев од међународног, преко државног, па све до локалног нивоа. Запослени у јединицама локалне самоуправе обављају послове који су од велике важности за локално становништво и од виталног интереса за функционисање једне локалне заједнице. Из тог разлога, веома је важно питање безбедности и здравља на раду лица која обављају те послове. У литератури готово да не постоји истраживање које се односи на безбедност и здравље на раду запослених у јединицама локалне самоуправе уопште, а нарочито таквих истраживања нема у државама Југоисточне Европе. Због тога је спроведено ово истраживање и указано је на то да постоји потреба за анализом њихове заштите кроз правну регулативу. Спроведено истраживање показује да ова категорија запослених није ни на који посебан начин препозната - ни у прописима о безбедности и здрављу на раду, а ни у прописима о локалној самоуправи. Пожељно је унапредити квалитет правне заштите безбедности и здравља на раду запослених у јединицама локалне самоуправе, јер ће то на крају допринети и унапређењу квалитета рада јединица локалне самоуправе. 